\title{
SAMUEL MIKLOS STERN
}

The tragic and unexpected death on 29 October 1969 of Samuel Stern was a severe loss to his many friends and colleagues everywhere, and to the field of Arabic and Islamic studies, enhanced for more than 20 years by his brilliant and numerous contributions. No less extraordinary than the depth and penetration of his genius was the range of his research, which included valuable studies in art and numismatics as well as work in the literature, philosophy, and history of Islam that will continue to serve as foundation and inspiration to future scholars of these subjects. In a period of topical and disciplinary specialization Stern was a polymath, and his part in the continuing progress of our studies may be likened to that of the pioneers and founders of Islamkunde in the nineteenth century. He was endowed with almost unbelievable energy and, in addition to the claims of his own research, always found time to help the many students who had come especially to Oxford to work with him. These, and all of us who knew the man, were witness to a kind of scholar all too rare in our century.

Samuel Miklos Stern was born in Tab, Hungary, on 22 November 1920. His studies in Jerusalem, begun in 1939 at the Hebrew University with Professors D. H. Baneth and S. D. Goitein, were interrupted by war service with the office of British censorship in Baghdād and Port Sudan. In 1947 he completed his studies in Jerusalem and spent the following years at St. Catherine's College, Oxford, in post-graduate research under the supervision of Sir Hamilton Gibb. After being awarded, in 1951, the degree of D.Phil., Stern was appointed Secretary General for the new edition of the Encyclopaedia of Islam, a post which he held until 1956. From 1956 to 1957 he was Assistant Keeper of Oriental Coins at the Ashmolean, and in that year was elected to a Research Fellowship in All Souls College. Since 1964 he was, in addition to his tenure of a Senior Research Fellowship at All Souls, University Lecturer in the History of Islamic Civilization. During his years at Oxford Stern accepted invitations to lecture at universities abroad, including Jerusalem and Philadelphia, but declined several offers of permanent professorial appointments in these and other universities. Though modest and retiring he was not a recluse. The charming and comfortable house in Bladon Close, where he lived with his close friends Dr. and Mrs. Walzer, was always open to those who came to Oxford in search of the advice and assistance which they had learned to recognize was part of his unstinting generosity.

In Jerusalem Stern's studies had combined Arabic and Hebrew with Romance philology and literature, and it was this auspicious combination that inspired his first research and earliest publications. That remarkable example of cultural and social symbiosis which was Muslim Spain had long been a subject of interest and study, but not often approached by a scholar with the requisite linguistic proficiencies and critical insight into literature as the expression of social ambients. It was Stern's merit to have discerned the role 
of courtly poetry, and in particular of the muwashshah and zajal, to be a form drawn upon and cultivated in common by representatives of the Muslim, Jewish, and Christian populations in al-Andalus. He was the first to distinguish and decipher the Romance kharja employed in Arabic and secular Hebrew poetry, and to delineate the part played in their elaboration by classical Arabic prosody and rhetoric. The extent to which subsequent scholarship stands in his debt and shadow is indicated by the work of inter alia P. Dronke and K. Heger. Stern's findings were published in a series of articles which appeared in the Spanish orientalist periodical Al-Andalus between 1948 and 1953 (vols. XIII-XVIII), as well as in his concise and erudite guide to the subject entitled Les chansons mozarabes: les vers finaux (kharjas) en espagnol dans les muwashshahs arabes et hébreux, Palermo, 1953 (reprinted by Bruno Cassirer, Oxford, 1964). Interest in a subject such as this naturally brought Stern into contact with the related problems of comparative literature so acutely reflected in the question of historical contact between Muslim and European lyric poetry during the late Middle Ages. Here his expertise and sound judgement provided a refreshing corrective to the wide-ranging and often simplistic generalizations so long current in that field of study. In precise and judicious terms Stern outlined and answered the question at a conference of the Centro Italiano di Studi sull'Alto Medioevo on the theme 'L'occidente e l'Islam nell'alto medioevo' held at Spoleto in April 1964 (published Spoleto, 1965). The influence of the Andalusian muwashshah was also radial, and Stern did not neglect the light which his discoveries had shed upon poetic and musical form in North Africa, set out in a fascinating paper read at the first Congreso de Estudios Árabes e Islámicos, at Cordova in 1962 (published Madrid, 1964).

Approximately ten years before his death Stern's interest turned to the study of Islamic documents and chancery practice, and it was then that our paths crossed. It was a great advantage to be able to call upon his knowledge of Arabic and Islamic history for a subject which at that time was still relatively unexplored. Arabic chancery documents had indeed been published, but perfunctorily edited and rarely analysed. It was the actual mechanics of the Muslim chancery which attracted his attention, and in a series of brilliant articles (BSOAS, xxIII, 3, 1960, xxvII, 1, 1964, xxIx, 2, 1966, and Oriens, xv, 1962) Stern depicted with painstaking care the machinery of the Egyptian chancery, together with an analysis of its attendant technical terminology, covering a period of five centuries. This work culminated in the publication of two books: Fätimid decrees (All Souls Studies, III, London, 1964) and Documents from Islamic chanceries (Oxford, [1966]). We were especially interested in the Arabic documents still to be found in Italian archives and had, one summer's afternoon in the garden of Villa Machiavelli near Florence, planned to produce a critical edition of Michele Amari's Diplomi arabi. This and other projects remained unfinished at the time of his death. Over the years, Stern had become an accomplished palaeographer, a judgement readily confirmed by a glance at the plates included in Fatimid decrees. I remember very 


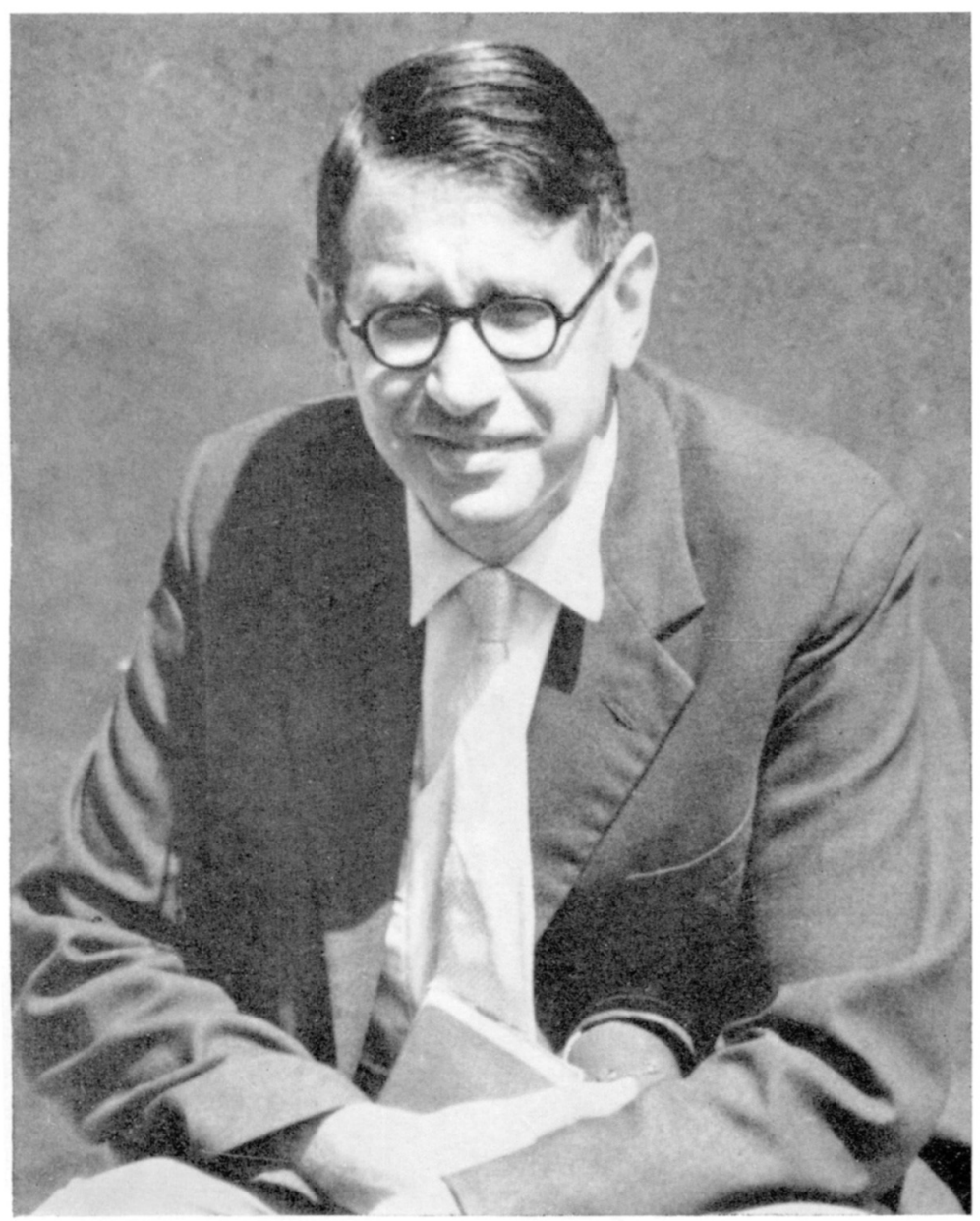

Samuel Miklos Stern

BSOAS, XXXIII] 
clearly my wonder, when some years ago I was at last able to see that famous document at the Coptic Museum in Old Cairo (Fatimid decrees, doc. I), that he had been able to decipher it at all, so poorly legible was its script and defective its state of preservation. Work of this sort demanded meticulous care and unending patience, in short, the sound philological method which Stern applied to all his studies.

In some ways even more important than his contributions to Spanish Muslim studies and Islamic Urkundenlehre, because it touched upon so many aspects of medieval Islam, was Stern's work on the origins and elaboration of Ismä'ilism. This too had been an early and abiding interest, and it is very sad indeed that his major work in that field remains uncompleted. One may gain an impression of the lines of inquiry which he was pursuing from a paper, both penetrating and provocative, read to a colloquium on 'L'élaboration de l'Islam ' convened at Strasbourg in June 1959 (published Paris, 1961). Here the artificial dichotomy between Ismā ${ }^{6} \bar{l} l i ̂$ and Qarmatian, the lack of historical continuity between (early) Ismāîli and (later) Ismā'ìli/Qarmatian, and the vexed problem of Fātimid genealogy are the objects of a fruitful if brief analysis, and it is a pleasure to note that these and other arguments are found amplified and carried to their logical conclusions in the book for which posthumous publication is planned in Oxford.

Of similar distinction were Stern's contributions to the field of Islamic philosophy. Through his long association with Dr. Walzer he was, not unexpectedly, interested in the transmission of Greek thought into Arabic, and especially in the efflorescence of Neoplatonic forms under Ismā'ìli cultural patronage. Perhaps the most valuable evidence of these interests is the study of Isaac Israeli which Stern published in collaboration with Professor Altmann in 1958 (OUP). Here, as in his works on Muslim Spain, one gains more than merely a glimpse of the extraordinary degree of intellectual and cultural symbiosis obtaining between the two peoples during the medieval history of Judaism and Islam. The influence of al-Kindi upon Isaac's thought and the manner in which his theories of revelation and prophetology exhibit as much of Muslim tafsir as of Rabbinic modes are but two aspects of the authors' portrayal of the intellectual environment of North Africa in the tenth century. In this study Stern carried further lines of investigation proposed by his great predecessor Ignaz Goldziher, and it is more than appropriate that one of his last undertakings should be the supervision of a translation into English of Muhammedanische Studien with revised and supplementary annotation (Vol. I, London, 1967), an achievement for which students of Islam in the English-speaking world have every reason to be grateful.

In March 1967 at one of the weekly meetings of the Institute of Jewish Studies at University College, London, Stern read a paper on the prophetology of the Mu'tazilite theologian 'Abd al-Jabbār. It was a brilliant performance and provoked a discussion which kept us there long after the time regularly allocated to the seminar. This paper (published with supplementary material 
in the Journal of Theological Studies, New Series, xvIII, 1, 1967, and xIx, 1, 1968) revealed yet another dimension of Stern's profound understanding of the phenomena of Islam. The study of religious polemic is notoriously difficult, and little of value has been done in the field of Muslim polemical literature since the pioneering work of M. Steinschneider. Fundamental to any exposition is establishment of criteria for discerning a polemicist's sources of information about the beliefs of his adversary, that is, whether these are derived from canonical or from apocryphal and sectarian literature, and to what extent transmission of such information has been adapted to the doctrinal terminology of the writer's own beliefs. Related to this are the problems of translation, official and popular, textual variants, and the structure of polemical discourse. For 'Abd al-Jabbār, Stern provided a detailed analysis of his sources of information, and was able to detect both terminological and ideological calques where these exist. As locus probans he selected the Docetic dispute and the Qur'anic reflexes of its ramifications in Judaeo-Christian polemic. In his first of several projected supplements $(J T S$, NS, xIX, 1, 1968) the antiquity of resistance to Pauline theology is amply demonstrated, in a manner which renders very topical this particular aspect of Muslim polemic. Work of such quality is still in its infancy, but promises valuable results by incorporating an Islamic dimension into the traditional material of Judaeo-Christian polemic.

Samuel Stern brought to all of these subjects both scholarship and imagination. Above all it was the care with which he examined and elucidated his sources that set his work apart from that of his predecessors and contemporaries. He was a philologist in the very best sense of a long and celebrated tradition, and his conclusions, always advanced with caution and reserve, inspired confidence. It may indeed be said that his scholarship represented a rare combination of meticulous preparation and sound judgement:

(Abot 2, 8)

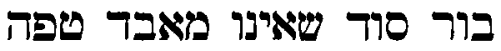

JOHN WANSBROUGH 